\title{
THREE SIDES OF THE SAME COIN? THE MAIN DIRECTIONS OF THE ENVIRONMENTAL MOVEMENT
}

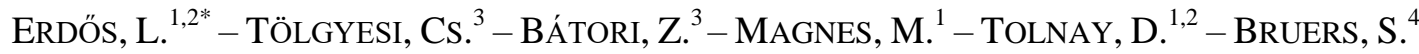 \\ ${ }^{1}$ Institute of Plant Sciences, University of Graz \\ 8010 Graz, Holteigasse 6., Austria \\ (phone: +43-316-380-5663; fax: +43-316-380-9880) \\ ${ }^{2}$ Institute of Ecology and Botany, MTA Centre for Ecological Research \\ 2163 Vácrátót, Alkotmány utca 2-4., Hungary \\ (phone: +36-28-360-147; fax: +36-87-448-006) \\ ${ }^{3}$ Department of Ecology, University of Szeged \\ 6726 Szeged, Közép fasor 52., Hungary \\ (phone: +36-62-546-951; fax: +36-62-546-949) \\ ${ }^{4}$ Department of Philosophy and Moral Science, Ghent University \\ 9000 Ghent, Blandijnberg 2, Belgium \\ (phone: +32-9-264-3982; fax: +32-9-264-4187) \\ *Corresponding author \\ e-mail:erdos.laszlo@okologia.mta.hu \\ (Received $8^{\text {th }}$ Mar 2017; accepted $19^{\text {th }}$ May 2017)
}

\begin{abstract}
Earlier publications about the main directions of the environmental movement have been incomplete. Some papers discussed the relationships between nature conservation and animal advocacy, but they either disregarded environmentalism, or treated it as a synonym of nature conservation. This latter is a conceptual error since it does not take into account the different primary objectives, distinct historical roots and dissimilar ethical standards of nature conservation and environmentalism. Although a few publications did recognise the difference between nature conservation and environmentalism, these papers failed to include animal advocacy into their an alyses. Consequently, a comprehensive overview of all three directions of the environmental movement is still lacking. In this article we argue that the environmental movement has three main directions: (1) nature conservation, (2) environmentalism and (3) animal advocacy. We analyse their main objectives, historical roots and ethical standards, and we scrutinise their relationships to one another. Distinguishing the three main directions will ease the use of clear ethical arguments supporting specific decisions. By clarifying the relationships among the main branches, our conceptual scheme will help to find allies and solve conflicts in applied conservation, animal advocacy and environmentalism. If the three directions join forces, there will be some reason for optimism.
\end{abstract}

Keywords: nature conservation, environmentalism, animal advocacy, environmental history, environmental ethics

\section{Introduction}

It is a commonplace that, in an environmental sense, we are at a critical point in history (e.g. Vitousek et al., 1997; Williams and Crutzen, 2013). Given the various types of destructions we face and the enormous diversity of people who want to be part of the solution, it is no wonder that considerable differences exist among the different groups of the environmental movement. Differences range from minor variances in emphasis to desperate combats. A total harmony may be unrealistic and undesirable, but 
a clear and accurate definition of the main directions may contribute to the identification of powerful ethical arguments, reveal the causes of conflicts and help solve them, and result in a better co-operation.

As public environmental awareness has been rapidly increasing since the middle of the twentieth century, the environmental movement has also become more and more diverse. At the same time, it has become increasingly obvious that the environmental movement is not a solid block, but it consists of considerably different branches. However, there have been relatively few attempts to analyse the main directions and their characteristics, let alone their relationships.

As disagreements between conservation biologists and animal advocates came to light (with a debate occasionally resulting in strong exaggerations and misinterpretations on both sides; e.g. Callicott, 1980; Regan, 1983; Sagoff, 1984), considerable attention was paid to define these two directions. (We see that there is a fundamental difference within animal advocacy, namely between animal welfare and animal rights, but for the purposes of the present article, there is no need to treat them separately.) As a result, scientists and philosophers have regularly restricted their attention to only two branches of the environmental movement: animal advocacy and nature conservation (e.g. Callicott, 1988; Ehrenfeld, 1991; Midgley, 1992; Jamieson, 1998; Perry and Perry, 2008; Paquet and Darimont, 2010; Keulartz, 2015). The first problem with the above distinction is that it does not give the full picture: environmentalism is either totally disregarded, or it is merged with nature conservation. The lack of distinction between nature conservation and environmentalism is a general phenomenon (e.g. Western, 1989; Norton, 2000; Switzer, 2003; DesJardins, 2006; McShane, 2007; O'Neill et al., 2008), the cause of which probably lies in the fact that the words 'nature' and 'environment' are used as synonyms. Fusing nature conservation and environmentalism is a conceptual error, which does not take into account their different primary objectives, distinct historical roots and dissimilar ethical standards. The second problem is that the conclusions concerning the relationships between conservation and animal advocacy were highly variable, from total irreconcilability (e.g. Saggoff, 1984) (Fig. 1a) to compatibility (e.g. Jamieson, 1998) (Fig. 1b).

There are extremely few publications that distinguish between nature conservation and environmentalism, recognising their different primary purposes (Margóczi, 1998; Heiland, 1999; Foreman, 2006; Gallé, 2013), or the different purposes plus the distinct historical traditions (Noss, 1999; Hunter and Gibbs, 2007). Unfortunately, the relationships between the two directions have never been explored in detail, although some publications noted that they are overlapping (e.g. Margóczi, 1998). In addition, none of the above publications regard animal advocacy as belonging to the environmental movement (Fig. 1c), which is unfortunate, to say the least.

Although Foreman (1991) clearly differentiated among the three main directions (i.e. nature conservation, environmentalism, animal advocacy), this was only in a brief footnote, without further considerations or analyses. The idea has not gotten much scientific attention nor has it been elucidated in detail.

In sum, a careful examination of the main aims, ethical principles and historical roots of the three directions within the environmental movement is still lacking. Also, their complex relationships have never been examined thoroughly, which may have farreaching theoretical and practical consequences.

In this article we argue that it is convenient and useful to distinguish between nature conservation and environmentalism, for several reasons. First, environmentalism is 
usually concerned about human welfare and human environment, which does not apply to conservation (Noss, 1999; Foreman, 2006; Hunter and Gibbs, 2007). Second, as a consequence of the above distinction, the ethical foundations differ considerably, environmentalism having a more human-centered focus, while conservation being nonanthropocentric (Margóczi, 1998). Third, the two branches have a rather different history: nature conservation has its roots in the nineteenth century activity of distinguished American writers and naturalists such as Ralph Waldo Emerson, Henry David Thoreau and John Muir, whereas environmentalism emerged in the second half of the twentieth century, marked by notable figures such as Rachel Carson, Barry Commoner and Denis Hayes (cf. Strong, 1988; Switzer, 2003; Hunter and Gibbs, 2007).

(a)

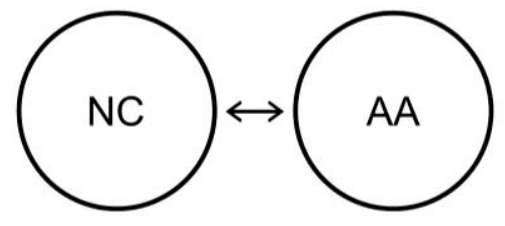

(c)

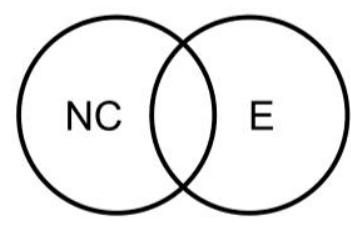

(b)

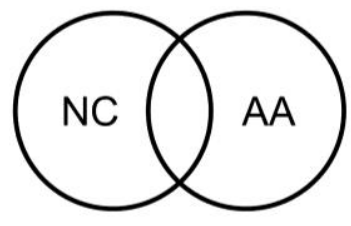

(d)

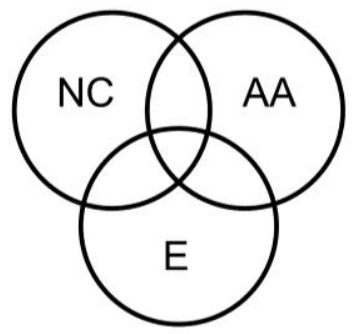

Figure 1. Relationships among the main directions of the environmental movement. (a)

Concepts exploring nature conservation and animal advocacy, regarding them as irreconcilable, (b) Concepts exploring nature conservation and animal advocacy, realising their compatible and overlapping character, (c) Concepts exploring nature conservation and environmentalism, regarding them as overlapping, (d) Our conceptual scheme exploring all three directions with considerable overlaps. NC: nature conservation, AA: animal advocacy (animal rights/welfare activism), E: environmentalism.

The conceptual scheme to be described in the present paper was built on the embryonic outlines of the three-way solution of Foreman (1991). Thus, unlike the overwhelming majority of the earlier publications, we suggest that three main directions should be recognised within the environmental movement: (1) nature conservation, (2) environmentalism, and (3) animal advocacy. We make an attempt to identify the primary aims of the three branches. We also give a basic insight into how different their historical backgrounds are. In addition, we try to identify the ethical principles underlying the three main directions. Our further goal is to clarify their relationships to one another. In doing so, we give some examples how a better co-operation of the three directions may be possible. 
We think that our clarification and the resulting conceptual scheme have the potential to contribute to a better usage of well-founded ethical arguments in applied nature conservation, environmentalism, and animal advocacy. Furthermore, areas of overlaps (where the aims of two or three directions converge) can be identified, which can help to find allies for particular environmental measures or actions. In other cases, our scheme may reveal the reasons underlying specific conflicts, and may help solve them. We hope our present work will contribute to an increased efficiency of the environmental movement.

\section{The main directions and their historical roots}

Nature conservation is often defined as an activity that aims to conserve species, natural communities, ecosystems and ecological processes (e.g. Soulé and Wilcox, 1980; Ehrlich and Ehrlich, 1981; Soulé, 1985, 1986; Primack, 1993, 2004; Begon et al., 1996; Gaston, 1998; Mascia et al., 2003; Borgerhoff Mulder and Coppolillo, 2005; Meffe et al., 2006). The primary focus of nature conservation is biodiversity; it intends to prevent or minimise unwanted loss in the diversity of life at several levels (e.g. genetic diversity of populations, species diversity, habitat diversity). It is important to emphasise that nature conservation does not necessarily intend to reach the highest possible biodiversity (it would be nonsense to plant invasive species into a species-poor habitat to increase its diversity). Instead, it seeks to maintain an appropriate level of diversity. In sum, nature conservation focuses on species, communities, and it does not engage in the welfare of individuals (Soulé, 1985).

The focus of nature conservation on natural and near-natural habitats, processes and diversity is understandable if one considers the beginnings of modern conservation. Till the nineteenth century, at least in the Western world, nature (or wilderness) was considered worthless, hostile and undesirable, something that had to be destroyed, tamed and exploited (Cronon, 1996; Herrmann, 2007). Among the first ones who recognised the aesthetic and spiritual values of nature was Emerson (1836). His followers, most notably Thoreau (1854) and Muir (1912) were fascinated by the wilderness, and took every opportunity to observe its beauties. For them, wilderness areas were sacred places. Their influence culminated in the work of Leopold (1949), who is rightly considered the father of nature conservation.

As for environmentalism, first we have to determine whose environment we want to protect. It has been recognised that there is no such thing as a common environment, which would be the same for every living being. Instead, there are at least as many environments as there are organisms (Juhász-Nagy, 1984, 1986; Bartholomew, 1987; Heiland, 1999; O'Neill et al., 2008). It seems clear that the primary aim of environmentalism is to optimise the environmental parameters of the human species (Margóczi, 1998; Heiland, 1999; Noss, 1999). The primary interest of environmentalism is not wilderness, nor ecosystems, nor diversity, but human environment. Preventing smog formation, reducing soil contamination, providing safe drinking water, protecting the ozone layer, lessening soil erosion, and so on, are all human-centered actions (although they are clearly beneficial for a variety of other organisms as well). Even combatting global climate change, one of today's main focal points in environmentalism, is mainly interested in the future of the human species, although we do not deny that concerns do exist for other species and natural communities as well. 
Environmentalism is considerably younger than nature conservation. The start of modern environmentalism is marked by the now legendary book of Carson (1962). Even though the horrible effects of pesticides on birds and other living creatures were a central issue, considerable attention was paid to the negative influences on human health and human environment. Other classics during this initial period of environmentalism also focused primarily on energy issues, air pollution, soil contamination, human overpopulation and climate change, while biodiversity was discussed as a marginal topic, or was not discussed at all (e.g. Boulding, 1966; Hardin, 1968; Meadows et al., 1972; Schumacher, 1973; Hayes, 1977; Gore, 1992). Thus, the focus clearly differs from that of the nineteenth century conservation (see also Wildes, 1995).

Animal advocacy is interested in the rights and/or well-being of individual animals. It does not focus on species but on individual organisms who have interests, welfare or a quality of life (Ehrenfeld, 1991). It aims to cease or lessen animal mortality and suffering evoked by humans.

Of the three directions discussed in this paper, animal advocacy has the longest tradition, dating back to at least the eighteenth century, with one of the most prominent forerunners being utilitarian philosopher Jeremy Bentham (Guither, 1998; Beers, 2006). In the nineteenth century the movement spread primarily in the UK and the US (Guither, 1998), and it gained new momentum in the twentieth century, with the publication of three landmark books in animal advocacy (Ryder, 1975; Singer, 1975; Regan, 1983).

\section{Ethical foundations}

If the three main directions of the environmental movement are recognised, the corresponding ethical bases should also be identified.

As noted by Soulé (1985), conservation biology tends to be holistic. It seems clear that so does conservation activity. Thus, nature conservation focuses on biological levels above individuals. In an ideal case, nature conservation is not human-centered (Soulé, 1985; Barry and Oelschlaeger, 1996). Correspondingly, the underlying ethical principle must be holistic and non-anthropocentric. The statement of Leopold (1949) may serve as a useful guiding principle: 'A thing is right when it tends to preserve the integrity, stability, and beauty of the biotic community. It is wrong when it tends otherwise.' This is an ecocentric ethic, as it focuses neither on humans nor on the welfare of individual organisms, but on whole ecological systems. Although other targets of nature conservation (species, processes, etc.) are not mentioned in this short normative claim, it is obvious that these are necessary for the integrity, stability and beauty of a community. Similar arguments emphasizing the non-instrumental (intrinsic) value of nature had appeared earlier (e.g. Muir, 1912), but Leopold's (1949) effect on current conservation ethics proved to be the greatest. In fact, according to Callicott (1990), a correct interpretation of Leopold's (1949) famous maxim is able to guide our current conservation activities.

One may argue that nature conservation is, to some extent, anthropocentric. In fact, some researchers differentiate between 'resource conservation' and 'preservation' (e.g. Callicott, 1990; Hunter and Gibbs, 2007). The distinction is rooted in the nineteenth century history of the movement, when 'resource conservation' placed an emphasis on an optimal use of natural resources for the benefit of present and future human 
generations, while 'preservation' favoured setting aside large natural areas where any major human activity should be prevented (Wildes, 1995; Wellock, 2007). Nowadays, both subfields are placed under the umbrella of conservation (Noss, 1999), but it is easy to recognise the human-centered view of the first approach. However, as pointed out by Madhusudan and Shankar Raman (2003) and Kareiva (2014), the two concepts are additive rather than mutually exclusive. Even though some conservation stakeholders place more emphasis on anthropocentric reasons for protecting nature, research has shown that most if not all of them share some fundamental ecocentric values (Berry et al., 2016). Scientists and practitioners have recognised that to gain public support for conservation efforts, we have to emphasise nature's goods and services for humans (e.g. Norton, 1991; Odenbaugh, 2003; see also Reyers et al., 2010; Lele et al., 2013). Nevertheless, the primary and most important reason to protect nature, at least for most conservationists, is nature itself (cf. Ehrenfeld, 1976; Ehrlich and Ehrlich, 1981; Soulé, 1985; Barry and Oelschlaeger, 1996; Foreman, 2006; McShane, 2007). Even conservationists who usually emphasise instrumental values may well prove ecocentric. Consider, for example, the statement of Kareiva (2014): 'I would prefer a world in which everyone believes that saving nature for nature's sake is simply the right thing to do and a moral imperative.' This is clearly an ecocentric view, even though he is regarded as rather anthropocentric (Hunter et al., 2014). The recognition of the benefits of nature for humans does not annul conservationists' thinking about the noninstrumental value of nature (Ehrenfeld, 1976). In addition, anthropocentric reasons for conservation efforts may have serious limits, while ecocentrism may be a more robust ethical foundation for nature conservation (Ehrenfeld, 1976; Callicott, 2002; Deliège and Neuteleers, 2015). Strongly related to this topic is the debate concerning the ecosystem services approach, especially the economic valuation of ecosystem services (e.g. Ridder, 2008; Norgaard, 2010; Gómez-Baggethun and Ruiz-Pérez, 2011; Salles, 2011; Costanza et al., 2014). In sum, we firmly believe that, at heart, nature conservation should be ecocentric. In contrast, disciplines and management activities with an exclusively anthropocentric base, focusing solely on the sustainable human use of resources (such as wildlife management or forestry) may be termed resource management or resourcism, but they should not be confused with nature conservation (Noss, 1999; Foreman, 2006).

As discussed above, environmentalism is primarily focused on humans. Therefore, it is reasonable to think that the underlying ethical principle is human-centered, i.e. anthropocentric. However, it is important to emphasise that this anthropocentrism is not equal to the conventionally accepted meaning of anthropocentrism. Anthropocentrism usually states that only humans have intrinsic value (or at least they have the largest intrinsic value), or that only humans are morally considerable (cf. Callicott, 2006; DesJardins, 2006; Nolt, 2015). We think that most environmentalists would strongly object to such a statement. Instead, environmentalism focuses on one species, ours, by protecting the environment we live in, without claiming that other organisms or ecological entities are less valuable. This concept may be termed 'environmental anthropocentrism'. Moreover, it is also clear that numerous other species also benefit from protecting the human environment.

At the base of animal advocacy (including both animal rights and animal welfare activism), there are individualistic ethics. Among individualistic ethics, sentiocentrism and biocentrism have to be evaluated. Both the utilitarian arguments of Singer (1975) and the rights-based theory of Regan (1983) pay major attention to the ability of feeling 
pain and pleasure. Therefore, both views can be regarded as sentiocentric (Callicott, 2006) or pathocentric (Wolf, 1996; Krebs, 1997). Biocentrism appears if our moral horizon is further expanded to include all living beings, as was done, for instance, by Schweitzer (1923), Goodpaster (1978) and Taylor (1981). Both sentiocentric and biocentric ethics are potential candidates for the ethical base of animal advocacy, since both concentrate on individuals. Nevertheless, sentiocentrism, focusing on sentient animals (and disregarding individual plants), seems to be more closely connected to current animal advocacy issues. It has to be noted that since Darwin $(1859,1871)$, sentiocentrism has a firm scientific basis, while traditional anthropocentric views are undermined and out-dated (see also Rachels, 1990; Erdős, 2015; Puryear et al., 2017).

It is doubtful whether one single ethical theory is capable of guiding our decisions in all of the difficult environmental situations (Norton, 2000). Instead, a value pluralism may be a better choice (Norton, 2000; Minteer and Collins, 2005; DesJardins, 2006; Carter, 2011; also see Wenz, 1993). Minteer and Collins (2005) argued that in many cases, nature-centered (i.e. ecocentric), human-centered (i.e. anthropocentric) and individual-centered (i.e. sentiocentric or biocentric) arguments should be considered simultaneously. For example, during ecological studies or conservation actions focusing on habitats or ecosystems, not only the holistic viewpoint (ecocentrism), but also animal welfare issues (sentiocentrism) and the effects on humans (anthropocentrism) should be taken into account.

Thus none of the above three ethical bases suggested for nature conservation, animal advocacy and environmentalism (ecocentrism, sentiocentrism and environmental anthropocentrism, respectively) should be considered universally valid. A careful examination and balance of these principles is needed, especially in the most difficult and complex cases.

\section{Areas of conflict and co-operation}

Although the three main directions of the environmental movement are separable, in the followings, we will demonstrate that they overlap considerably (Fig. 1d). If, for example, a tropical rainforest is set aside as a reserve, this may be considered an action that belongs to nature conservation, since the primary aim was probably the preservation of habitats and species. At the same time, however, large amounts of carbon are sequestrated in the biomass, which would contribute to global warming if the forest was destroyed. Thus, the designation of the reserve fits the goals of environmentalism. Finally, it also fits animal advocacy viewpoints, for it is quite obvious that no wild animal has a chance to a decent life without a natural habitat (cf. Taylor, 1981; Jamieson, 1998; Paquet and Darimont, 2010).

We do not deny that conflicts arise, but the above example shows that a co-operation of the three branches is possible and desirable. To give an exhaustive analysis of conflicts and solutions is not the aim of the present paper. In the following sections, we only want to give a basic insight into areas where conflicts may emerge, and fields where there are great potentials for co-operation. We will focus on the relationship between nature conservation and animal advocacy, but the other two pairs of the triangle will also be discussed briefly. 


\section{Nature conservation versus animal advocacy}

Confrontation, as already noted in the Introduction, is well-known between nature conservationists and animal advocates. The cause is simple: animal advocates care for individuals, while nature conservation is interested in species, habitats, etc. However, the common points should not be neglected either. For example, both branches are put under the umbrella of 'green issues' by the public (Perry and Perry, 2008). Most conservationists do care for individual's welfare, and most animal advocates value natural communities (Perry and Perry, 2008). In addition, the membership of animal advocacy and conservation groups overlaps considerably (Ehrenfeld, 1991; Jamieson, 1998). Finally, they form a common platform, since both directions reject anthropocentric views common and dominant in western societies (Callicott, 1988; Paquet and Darimont, 2010). It has been shown that open and rational dialogues between the two groups may reveal that, despite some differences, they do agree concerning several issues (Thompson and Lapointe, 1995). As Aitken (1997) noted, concerns for individual animals do not necessarily contradict conservation goals.

Conservation of a habitat or a species very often requires the elimination of a nonnative animal species, and the killing of the unwanted individuals may seem a plausible solution, which, quite naturally, is not welcome by animal advocates. However, even in this seemingly inextricable case, the co-operation has proven possible and mutually beneficial (Perry and Perry, 2008). First of all, preventing the establishment of potential invasive species corresponds to the ethical principles of both directions. Second, if the invasive species has already arrived, alternative measures such as live-trapping and subsequent neutering or translocation (instead of killing) should be discussed between animal advocates and conservationists as early as possible. Perry and Perry (2008) concluded that the two groups should make every effort to find a common ground, and this could result in conservation actions that are acceptable for both parties. Killing invasive species all too often occurs routinely and easily, and killing is usually carried out in the name of conservation even if it serves other goals (van Dooren, 2011). We think conservationists and animal advocates agree that similar practices should be abandoned.

Feral and unowned cats may cause considerable damage to native fauna (Longcore et al., 2009) (although some argue that they only have a limited and short-term effect on native bird and mammal populations; Jarvis, 1990). As a possible solution to reduce the negative impacts on wildlife, the killing of the cats is usually proposed, which is unacceptable for most animal advocates. As a compromise, trap-neuter-release (TNR) programs have been introduced as non-lethal alternatives, during which cats are sterilised and put back where they were trapped. Although animal advocates claim that the method is efficient (e.g. Levy et al., 2003), conservationists have serious doubts and state that cat colony sizes do not decrease fast enough (e.g. Longcore et al., 2009). Irreconcilable as the debate may seem, the common ground is easily reached when we consider that the long-term reduction in the number of stray animals is the goal for both sides. For this, neither lethal methods, nor TNR-programs will be satisfactory; rather, the source of the problem has to be treated. The propagation of responsible animal keeping is necessary, to prevent steady new supplies to free-roaming cat populations. Encouraging citizens to neuter their cats would contribute to a significant decrease in unwanted reproduction, lessening the damage to natural values and at the same time avoiding unnecessary animal suffering (Jarvis, 1990). For a fruitful co-operation, animal advocates have to accept the concern of conservationists for wildlife, and 
conservationists should appreciate cat-lovers' enormous efforts in neutering and adopting unowned cats, often without any funding. It should also be kept in mind that TNR-schemes combined with adopting of at least some of the cats can bring relatively fast successes in the reduction of unowned cat population sizes (Levy et al., 2003).

One of the most promising areas of co-operation between nature conservation and animal advocacy groups is, somewhat surprisingly, meat production. Tens of billions of animals are confined to extremely small areas in 'factory farms' worldwide, living under terrible conditions (Nierenberg, 2006; Halweil and Nierenberg, 2008). At the same time, at least in many European and Asian temperate landscapes, grazing is considered an efficient conservation management, yet several valuable grasslands are undergrazed or not grazed at all (Zahn et al., 2007; Peeters, 2009; Erdős et al., 2011; Kiss et al., 2011; Házi et al., 2012; Saláta et al., 2012; Wichmann et al., 2013; Mardari and Tănase, 2016). Market trends clearly show that consumers prefer animal products that have been produced according to stronger animal welfare standards (i.e. products that originate from free-ranging animals) (e.g. Phan-Huy and Fawaz, 2003; Halweil and Nierenberg, 2008; Ventura et al., 2015). It is not difficult to recognise the common ground of conservationists and animal welfarists, although it has to be noted that those who hold the animal rights position would not join this platform, since they refuse any kind of animal exploitation, irrespective of how the animals are kept (e.g. Regan, 1983; Francione, 2008). However, even they admit that free-ranging animals have a better life than those living in confinement.

Another promising area of co-operation is the action against the overharvest of animal populations, which is a serious conservation threat, and at the same time it has obvious effects on the animals' welfare. Whaling, for example, is in the crosshairs of both animal advocates and conservationists. In addition, the (mainly illegal) trade of other animals and animal products should also be considered in this regard. Baker et al. (2013) suggested that an efficient collaboration between animal advocates and conservationists would be most welcome in issues like this.

Not only do some animal welfare issues have a practical conservation relevance, but they may be of scientific importance as well. For example, toe clipping of amphibians in mark-recapture surveys (the removing of a combination of their digits) has been a wide-spread tool. Animal advocates' arguments against the unethical practice may have been automatically rejected and declared 'unscientific' once, but as we now know, the method in fact distorts scientific results and has conservation effects due to reduced survival of marked individuals (May, 2004).

\section{Nature conservation versus environmentalism}

A conflict has recently come to light between the use of renewable energy and the conservation of natural values, as certain disadvantages of alternative energy sources have been revealed. For example, the large-scale application of solar energy facilities in natural habitats (e.g. deserts) has various direct and indirect detrimental influences on native species (Lovich and Ennen, 2011). Wind turbines also proved to have serious adverse effects on wildlife (Kuvlesky et al., 2007; Lin 2017). Although negative impacts may not be completely eliminated, they can be minimised through careful planning (e.g. Stewart et al., 2007; Lin 2017). As the need for renewable energy increases, the co-operation of environmental engineers and conservation biologists is desperately needed. 
Strongly related to this issue are the adverse effects of biomass production for providing 'green' energy, which usually needs huge areas of land. Needless to say, biomass monocultures of fast-growing plants totally disrupt native communities (e.g. Abbasi and Abbasi, 2010; Gomiero et al., 2010) and are often objected by conservationists. However, the conflict is not as serious as it may seem at first glance. For example, biomass production that results in deforestation is not only unwanted from a conservation perspective, but it is questionable from an environmentalist's point of view, since its net effect is likely to exacerbate global warming (Field et al., 2007). A compromise may be possible in some cases, if, for example, traditional agroforestry practices using biomass energy are re-established (Plieninger and Bens, 2008), or used cooking oil is converted to biofuel.

\section{Animal advocacy versus environmentalism}

Conflicts between animal advocate groups and environmentalists have probably not been as apparent as in the previous two cases. Nonetheless, it should be mentioned that environmentalists sometimes refer to the fact that keeping companion animals is environmentally destructive, mainly because of the meat-based diet of the pets (Rushforth and Moreau, 2013). However, negative impacts can be reduced with conscious selection of the pet food type. Moreover, it should be kept in mind that one of the main goals of the animal advocacy groups is the reduction in the number of companion animals, through the propagation of neutering and responsible animal keeping. Moreover, some animal advocates strongly oppose the breeding of pets, claiming that no more animals should be brought into existence just to be abused or exploited later by cruel or indifferent humans (Francione, 2008). (Of course, animal advocates insist that we must care for animals who are already alive.) In fact, what seems to be a conflict can turn into a common ground by close inspection: Action against careless or profit-oriented breeding reduces environmental harm and avoids unnecessary animal suffering.

It is well-known that, besides being responsible for incredible animal suffering, intensive animal farms also have highly destructive effects on the environment by producing greenhouse gases and causing water pollution (Koneswaran and Nierenberg, 2008; Ilea, 2009; Rossi and Garner, 2014; Waldau, 2011). Several solutions may be possible, ranging from a reduction in meat consumption (e.g. Halweil and Nierenberg, 2008) to the avoidance of products from 'factory farms' (e.g. Appleby, 2005) to becoming vegetarian or vegan (e.g. Hill, 1996), all of which benefit animals and the environment at the same time (e.g. Goodland, 1997; Jamieson, 1998; Halweil and Nierenberg, 2008; Jankielsohn, 2015). In some or most of the above cases, there is much room for animal advocates and environmentalists to co-operate.

\section{Conclusions}

To efficiently combat today's various environmental challenges, we have to see where we have come from, and what our ultimate goal is. In this paper, expanding the ideas of Margóczi (1998), Noss (1999) and Hunter and Gibbs (2007), we differentiated between environmentalism and nature conservation. As a result, building on the proposal of Foreman (1991), we identified and defined the three main directions of the environmental movement: nature conservation, environmentalism and animal advocacy. We are aware that the three areas overlap considerably. We also 
see that they may further be subdivided. Nevertheless, we think that the use of the three basic categories is justified by their different emphases, distinct ethical principles and different historical roots.

Although conflicts do exist among the three directions, we think that they can be overcome if we understand the underlying reasons. Members of the three directions should try to understand each other's views. As we demonstrated with some examples, the areas for co-operation are huge and promising (Fig. 1d). Not only are the three directions reconcilable in most cases, they have much in common.

Earlier works either focused on nature conservation and animal advocacy, and disregarded environmentalism, or examined nature conservation and environmentalism, but did not consider animal advocacy. As a result, the complex inter-relationships among the three directions remained unexplored. In contrast, our conceptual scheme takes into account all three directions. One advantage of this is that it may help reveal ethical or historical reasons behind specific conflicts. On the other hand, it may ease the identification of convergences, which could support finding allies for particular measures or actions. All directions of the environmental movement typically have serious budgetary, staff and time constraints. Thus, both the rapid solution of conflicts and joining forces in converging situations may be essential if we are to increase the effectiveness of the environmental movement. We hope our conceptual scheme is one step in that direction.

As it was suggested in the previous sections, challenging humankind's present meat production and consumption practices is a focal point where overlaps exist among the different directions. First, it seems clear that a shift from an animal-based towards a plant-based diet in Western countries could be a win-win-win situation for nature conservation, environmentalism and animal advocacy. Nature conservationists may consider that 'the livestock sector may well be the leading player in the reduction of biodiversity' (Steinfeld et al., 2006). Environmentalists can be concerned about livestock's resource intensity (requiring a lot of agricultural land, water and energy) and its high levels of pollution (emissions of greenhouse gases, acidifying gases, reactive nitrogen compounds, veterinary medicines and pesticides). Animal advocates care about the immense suffering of farm animals. Thus, cutting down meat consumption could be one of the great challenges of the twenty-first century (Rösch, 2002, Stoll-Kleemann, 2014). It must be emphasized that, as high meat consumption has negative social and health effects, producing less meat could mean a win situation for other fields beyond the environmental movement as well (e.g. Hill, 1996; Stoll-Kleemann, 2014, Westhoek et al., 2014).

Second, animal-friendly and environmentally friendly methods should be supported. According to Appleby (2005), improved animal welfare in farms promotes environmental sustainability and vice versa, because both approaches regard agriculture mainly as a biological rather than a mere technological process. At the very least, meat and other animal products from cropland and resource intensive low-nature-value farming systems, including 'factory farms', should be avoided. Unfortunately, even small-scale farms are environmentally harmful and animals have in some cases as miserable lives as in intensive farming. It is clear that we should make every effort to avoid animal products from each of these deeply unethical sources. It is important to point out here that, according to Curry (2011), organic and animal-friendly farming would be able to feed the whole human population on Earth, provided that global meat consumption is limited. 
Third, adopting a vegetarian or vegan lifestyle will have the greatest positive effect on animals, nature, and the environment. Pluhar (2009) concluded that a vegetarian diet (and possibly in-vitro meat production) may be the best alternative to factory farming, while Deckers (2009) claims that veganism is even better and more consistent both from an environmentalist's and an animal advocate's point of view.

The above examples clearly show that challenging intensive and cruel animal farms is a key point where animal advocates, conservationists, and environmentalists can agree and work together (Regan, 1983; DeGrazia, 2002; Halweil and Nierenberg, 2008; Gjerris et al., 2011; Gjerris, 2015; Hayes and Hayes, 2015). However, it sometimes appears that a strong collaboration between the nature conservation, environmental and animal advocacy movements is hindered by an obstacle, a psychological bias. When there is too much justification, such as in a win-win situation, motivation can be undermined. Regarding a shift in diet away from animal products, some environmentalists seem scared to talk about animal suffering. Meanwhile, some animal rights activists invest a lot of time and energy criticising other people who eat vegan or want to become vegan due to health or environmental reasons. Animal advocates think that the health and environmental vegans have the wrong objectives and some even believe that advocating veganism for health and environmental reasons is counterproductive. They believe that one should always and only refer to the animal rights objective when promoting veganism. This phenomenon is also at work in other areas, such as family planning (access to contraceptives to prevent unwanted pregnancies): women rights activists who campaign for family planning as a reproductive right often criticize environmentalists who propose family planning as an effective means to limit the environmental impact from human overpopulation. According to those feminist advocates, environmental concerns should not be a valid objective for promoting family planning. Reversely, many environmentalists and conservationists are reluctant to talk about family planning as a means to decrease population growth. We can call this pyschological phenomenon the 'single objective bias', which can be strong enough to generate mutual hostility between the movements. When this single objective bias can be overcome, all three movements will gain strong benefits in an effective collaboration.

We are facing great challenges, and there is no doubt that solutions will be easier with co-operation. Probably the best-known example for synergism among the main directions of the environmental movement is provided by Jane Goodall, who is a dedicated conservationist, an animal advocate and an environmentalist at the same time (see for example: Goodall and Berman, 1999; Goodall and Bekoff, 2002; Goodall et al., 2005).

Besides being a role-model for millions, Jane Goodall has also been a lifelong optimist. If conservationists, environmentalists and animal advocates join forces, perhaps there will be some reason for optimism.

Acknowledgements. This work was supported by the Hungarian Eötvös Scholarship of the Hungarian Scholarship Board and the National Youth Excellence Scholarship (NTP-EFÖ-P-15-0630). 


\section{REFERENCES}

[1] Abbasi, T., Abbasi, S. A. (2010): Biomass energy and the environmental impacts associated with its production and utilization. - Renewable and Sustainable Energy Reviews 14: 919-937.

[2] Aitken, G. (1997): Conservation and individual worth. - Environmental Values 6: 439454.

[3] Appleby, M. C. (2005): Sustainable agriculture is humane, humane agriculture is sustainable. - Journal of Agricultural and Environmental Ethics 18: 293-303.

[4] Baker, S. E., Cain, R., van Kesteren, F., Zommers, Z. A., D’Cruze, N., Macdonald, D. W. (2013): Rough trade: animal welfare in the global wildlife trade. - Bioscience 63: 928938.

[5] Barry, D., Oelschlaeger, M.. (1996): A science for survival: values and conservation biology. - Conservation Biology 10: 905-911.

[6] Bartholomew, G. A. (1987): Interspecific comparison as a tool for ecological physiologists. - In: Feder, M. E., Bennett, A. F., Burggren, W. W., Huey, R. B. (eds.) New directions in ecological physiology. Cambridge University Press, Cambridge, pp. 11-35.

[7] Beers, D. L. (2006): For the prevention of cruelty: The history and legacy of animal rights activism in the United States. - Ohio University Press, Athens.

[8] Begon, M., Harper, J. L., Townsend, C. R. (1996): Ecology: individuals, populations and communities. 3rd edition. - Blackwell, Oxford.

[9] Berry, P. M., Fabók, V., Blicharska, M., Bredin, Y. K., Llorente, M. G., Kovács, E., Geamana, N., Stanciu, A., Termansen, M., Jääskeläinen, T., Haslett, J. R., Harrison, P. A. (2016): Why conserve biodiversity? A multi-national exploration of stakeholders' views on the arguments for biodiversity conservation. - Biodiversity and Conservation doi:10.1007/s10531-016-1173-z

[10] Borgerhoff Mulder, M., Coppolillo, P. (2005): Conservation: linking ecology, economics, and culture. - Princeton University Press, Princeton.

[11] Boulding, K. E. (1966): The economics of the coming Spaceship Earth. - In: Jarrett, H. (ed.) Environmental quality in a growing economy. JohnS Hopkins University Press, Baltimore, pp. 3-14.

[12] Callicott, J. B. (1980): Animal liberation: a triangular affair. - Environmental Ethics 2: 311-338.

[13] Callicott, J. B. (1988): Animal liberation and environmental ethics: Back together again. - Between the Species 5: 163-169.

[14] Callicott, J. B. (1990): Whither conservation ethics? - Conservation Biology 4: 15-20.

[15] Callicott, J. B. (2002): The pragmatic power and promise of theoretical environmental ethics: forging a new discourse. - Environmental Values 11: 3-25.

[16] Callicott, J. B. (2006): Conservation values and ethics. - In: Groom, M. J, Meffe, G. K., Carroll, C. R. (eds.) Principles of conservation biology. 3rd edition. Sinauer Associates, Sunderland, pp. 111-135..

[17] Carson, R. L. (1962): Silent spring. - Houghton Mifflin Company, Boston.

[18] Carter, A. (2011): Towards a multidimensional, environmentalist ethic. - Environmental Values 20: 347-374.

[19] Costanza, R., de Groot, R., Sutton, P., van der Ploeg, S., Anderson, S. L., Kubiszewski, I., Farber, S., Turner, R. K. (2014): Changes in the global value of ecosystem services. Global Environmental Change 26: 152-158.

[20] Cronon, W. (1996): The trouble with wilderness: or, getting back to the wrong nature. Environmental History 1: 7-28.

[21] Curry, P. (2011): Ecological ethics: An introduction. - Polity Press, Cambridge.

[22] Darwin, C. (1859). On the origin of species by means of natural selection or the preservation of favoured races in the struggle for life. - John Murray, London. 
[23] Darwin, C. (1871): The descent of man, and selection in relation to sex. - John Murray, London.

[24] Deckers, J. (2009): Vegetarianism, sentimental or ethical? - Journal of Agricultural and Environmental Ethics 22: 573-597.

[25] DeGrazia, D. (2002): Animal rights: A very short introduction. - Oxford University Press, Oxford.

[26] Deliège, G., Neuteleers, S. (2015): Should biodiversity be useful? Scope and limits of ecosystem services as an argument for biodiversity conservation. - Environmental Values 24: $165-182$.

[27] DesJardins, J. R. (2006): Environmental ethics. An introduction to environmental philosophy. 4th edition. - Thomson Wadsworth, Belmont.

[28] Ehrenfeld, D. (1976): The conservation of non-resources. - American Scientist 64: 648656.

[29] Ehrenfeld, D. (1991): Conservation and the rights of animals. - Conservation Biology 5: $1-3$.

[30] Ehrlich, P. R., Ehrlich A. H. (1981): Extinction: The causes and consequences of the disappearance of species. - Random House, New York.

[31] Emerson, R. W. (1836): Nature. - James Munroe and Company, Boston.

[32] Erdős, L. (2015): Veganism versus meat-eating, and the myth of "root capacity": A response to Hsiao. - Journal of Agricultural and Environmental Ethics 28: 1139-1144.

[33] Erdős, L., Bátori, Z., Zalatnai, M., Margóczi, K., Tolnay, D., Cseh, V., Arsene, G. G., Körmöczi, L. (2011): Comparison of two neighbouring alkaline grasslands with different land uses: a conservation management perspective. - Acta Botanica Hungarica 53: 89100.

[34] Field, C. B., Campbell, J. E., Lobell, D. B. (2007): Biomass energy: the scale of the potential resource. - Trends in Ecology and Evolution 23: 65-72.

[35] Foreman, D. (1991): The new conservation movement. - Wild Earth 1: 6-12.

[36] Foreman, D. (2006): Take back the conservation movement. - International Journal of Wilderness 12: 4-31.

[37] Francione, G. L. (2008): Animals as persons: essays on the abolition of animal exploitation. - Columbia University Press, New York.

[38] Gallé, L. (2013): A szupraindividuális biológia alapjai: populációk és közösségek ökológiája. - JATEPress, Szeged.

[39] Gaston, K. J. (1998): Biodiversity. - In: Sutherland, W. J. (ed.) Conservation science and action. Blackwell, Oxford, pp. 1-19.

[40] Gjerris, M. (2015): Willed blindness: a discussion of our moral shortcomings in relation to animals. - Journal of Agricultural and Environmental Ethics 28: 517-532.

[41] Gjerris, M., Gamborg, C., Röcklinsberg, H., Anthony, R. (2011): The price of responsibility: ethics of animal husbandry in a time of climate change. - Journal of Agricultural and Environmental Ethics 24:331-350.

[42] Gómez-Baggethun, E., Ruiz-Pérez, M. (2011): Economic valuation and the commodification of ecosystem services. - Progress in Physical Geography 35: 613-628.

[43] Gomiero, T., Paoletti, M. G., Pimentel, D. (2010): Biofuels: efficiency, ethics, and limits to human appropriation of ecosystem services. - Journal of Agricultural and Environmental Ethics 23: 403-434.

[44] Goodall, J., Bekoff, M. (2002): The ten trusts: what we must do to care for the animals we love. - HarperCollins, San Francisco.

[45] Goodall, J., Berman, P. (1999): Reason for hope: a spiritual journey. - Warner Books, New York.

[46] Goodall, J., McAvoy, G., Hudson, G. (2005): Harvest for hope: A guide for mindful eating. - Warner Books, New York.

[47] Goodland, R. (1997): Environmental sustainability in agriculture: diet matters. Ecological Economics 23: 189-200. 
[48] Goodpaster, K. E. (1978): On being morally considerable. - The Journal of Philosophy 75: 308-325.

[49] Gore, A. (1992): Earth in the balance: Ecology and the human spirit. - Houghton Mifflin, Boston.

[50] Guither, H. D. (1998): Animal rights: History and scope of a radical social movement. Southern Illinois University Press, Carbondale.

[51] Halweil, B., Nierenberg, D. (2008): Meat and seafood: The global diet's most costly ingredients. - In: Starke, L. (ed.) State of the World 2008: Innovations for a sustainable economy. Earthscan, London, pp. 61-74.

[52] Hardin, G. (1968): The tragedy of the commons. - Science 162: 1243-1248.

[53] Hayes, D. (1977) Rays of hope: the transition to a post-petroleum world. - W. W. Norton and Company, New York.

[54] Hayes, D., Hayes, G. B. (2015): Cowed: the hidden impact of 93 million cows on America's health, economy, politics, culture, and environment. - Norton and Company, New York.

[55] Házi, J., Penksza, K., Bartha, S., Hufnagel, L., Tóth, A., Gyuricza, Cs., Szentes, Sz., (2012): Cut mowing and grazing effects with grey cattle on plant species composition in case of Pannon wet grasslands. - Applied Ecology and Environmental Research 10: 223231.

[56] Heiland, S. (1999): Voraussetzungen erfolgreichen Naturschutzes. - Ecomed Verlag, Landsberg/Lech.

[57] Herrmann, B. (2007): Natur und Mensch in Mitteleuropa im letzten Jahrtausend: eine interdisziplinäre Umweltgeschichte. - In: Deigele, C. (ed.) Natur und Mensch in Mitteleuropa im letzten Jahrtausend. Pfeil Verlag, München, pp. 125-136.

[58] Hill, J. L. (1996): The case for vegetarianism: Philosophy for a small planet. - Rowman and Littlefield, Lanham.

[59] Hunter, M. L., Gibbs, J. (2007): Fundamentals of conservation biology. 3rd edition. Blackwell Publishing, Malden.

[60] Hunter, M. L., Redford, K. H., Lindenmayer, D. B. (2014): The complementary niches of anthropocentric and biocentric conservationists. - Conservation Biology 28: 641-645.

[61] Ilea, R. C. (2009): Intensive livestock farming: global trends, increased environmental concerns, and ethical solutions. - Journal of Agricultural and Environmental Ethics 22: 153-167.

[62] Jamieson, D. (1998): Animal liberation is an environmental ethic. - Environmental Values 7: 41-57.

[63] Jankielsohn, A. (2015): The hidden cost of eating meat in South Africa: what every responsible consumer should know. - Journal of Agricultural and Environmental Ethics 28: 1145-1157.

[64] Jarvis, P. J. (1990): Urban cats as pests and pets. - Environmental Conservation 17: 169171.

[65] Juhász-Nagy, P. (1984): Beszélgetések az ökológiáról. - Mezőgazdasági Kiadó, Budapest.

[66] Juhász-Nagy, P. (1986): Egy operatív ökológia hiánya, szükséglete és feladatai. Akadémiai Kiadó, Budapest.

[67] Kareiva, P. (2014): New conservation: Setting the record straight and finding common ground. - Conservation Biology 28: 634-636.

[68] Keulartz, J. (2015): Captivity for conservation? Zoos at a crossroads. - Journal of Agricultural and Environmental Ethics 28: 335-351.

[69] Kiss T., Lévai, P., Ferencz, Á., Szentes, Sz., Hufnagel, L., Nagy, A., Balogh, Á., Pintér, O., Saláta, D., Házi, J., Tóth, A., Wichmann, B., Penksza, K. (2011): Change of composition and diversity of species and grassland management between different grazing intensity in Pannonian dry and wet grasslands. - Applied Ecology and Environmental Research 9: 197-230. 
[70] Koneswaran, G., Nierenberg, D. (2008): Global farm animal production and global warming: impacting and mitigating climate change. - Environmental Health Perspectives 116: $578-582$.

[71] Krebs, A. (1997): Discourse ethics and nature. - Environmantal Values 6: 269-279.

[72] Kuvlesky, W. P. Jr., Brennan, L. A., Morrison, M. L., Boydston, K. K., Ballard, B. M., Bryant, F. C. (2007): Wind energy development and wildlife conservation: challenges and opportunities. - The Journal of Wildlife Management 71: 2487-2498.

[73] Lele, S., Springate-Baginski, O., Lakerveld, R., Deb, D., Dash, P. (2013): Ecosystem services: origins, contributions, pitfalls, and alternatives. - Conservation and Society 11: 343-358.

[74] Leopold, A. (1949): A Sand county almanac. - Oxford University Press, New York.

[75] Levy, J. K., Gale, D. W., Gale, L. A. (2003): Evaluation of the effect of a long-term trapneuter-return and adoption program on a freeroaming cat population. - Journal of the American Veterinary Medical Association 222: 42-46.

[76] Lin, S.-C. (2017): A survey and study of towerkills and wind turbine kills. - Applied Ecology and Environmental Research 15: 589-607.

[77] Longcore, T., Rich, C., Sullivan, L. M. (2009): Critical assessment of claims regarding management of feral cats by trap-neuter-return. - Conservation Biology 23: 887-894.

[78] Lovich, J. E., Ennen, J. R. (2011): Wildlife conservation and solar energy development in the desert Southwest, United States. - Bioscience 61: 982-992.

[79] Madhusudan, M. D., Shankar Raman, T. R. (2003): Conservation as if biological diversity matters: preservation versus sustainable use in India. - Conservation and Society 1: 49-59.

[80] Mardari, C. Tănase, C. (2016): Plant diversity-environment relationships in xeric grasslands of north-eastern Romania. - Applied Ecology and Environmental Research 14: 111-127.

[81] Margóczi, K. (1998): Természetvédelmi biológia. - JATEPress, Szeged.

[82] Mascia, M. B., Brosius, J. P., Dobson, T. A., Forbes, B. C., Horowitz, L., McKean, M. A., Turner, N. J. (2003): Conservation and the social sciences. - Conservation Biology 17: 649-650.

[83] May, R. M. (2004): Ethics and amphibians. - Nature 431: 403.

[84] McShane, K. (2007): Anthropocentrism vs. nonanthropocentrism: why should we care? Environmental Values 16: 169-186.

[85] Meadows, D. H., Meadows, D. L., Randers, J., Behrens, W. W. III. (1972): The limits to growth. - Universe Books, New York.

[86] Meffe, G. K., Carroll, C. R., Groom, M. J. (2006): What is conservation biology? - In: Groom, M. J., Meffe, G. K., Carroll, C. R. (eds.) Principles of conservation biology. 3rd edition. Sinauer Associates, Sunderland, pp. 3-25.

[87] Midgley, M. (1992): Beasts versus the biosphere? - Environmental Values 1: 113-121.

[88] Minteer, B. A., Collins, J. P. (2005): Why we need an ecological ethics. - Frontiers in Ecology and the Environment 3: 332-337.

[89] Muir, J. (1912): The Yosemite. - The Century Company, New York.

[90] Nierenberg, D. (2006): Rethinking the global meat industry. - In: Nierenberg, D. (ed.). State of the World 2006: The challenge of global sustainability. Earthscan, London, pp. 24-40.

[91] Nolt, J. (2015): Environmental ethics for the long term. - Routledge, New York.

[92] Norgaard, R. (2010): Ecosystem services: from eye-opening metaphor to complexity blinder. - Ecological Economics 69: 1219-1227.

[93] Norton, B. G. (1991): Toward unity among environmentalists. - Oxford University Press, New York.

[94] Norton, B. G. (2000): Biodiversity and environmental values: in search of a universal earth ethic. - Biodiversity and Conservation 9: 1029-1044.

[95] Noss, R. (1999): Is there a special conservation biology? - Ecography 22: 113-122. 
[96] Odenbaugh, J. (2003): Values, advocacy and conservation biology. - Environmental Values 12: 55-69.

[97] O'Neill, J., Holland, A., Light, A. (2008): Environmental values. - Routledge,London.

[98] Paquet, P. C., Darimont, C. T. (2010): Wildlife conservation and animal welfare: two sides of the same coin? - Animal Welfare 19: 177-190.

[99] Peeters, A. (2009): Importance, evolution, environmental impact and future challenges of grasslands and grassland-based systems in Europe. - Grassland Science 55: 113-125.

[100] Perry, D., Perry, G. (2008): Improving interactions between animal rights groups and conservation biologists. - Conservation Biology 22: 27-35.

[101] Phan-Huy, S.A., Fawaz, R. B. (2003): Swiss market for meat from animal-friendly production - responses of public and private actors in Switzerland. - Journal of Agricultural and Environmental Ethics 16: 119-136.

[102] Plieninger, T., Bens, O. (2008): How the emergence of biofuels challenges environmental conservation. - Environmental Conservation 34: 273-275.

[103] Pluhar, E. B. (2009): Meat and morality: alternatives to factory farming. - Journal of Agricultural and Environmental Ethics 23: 455-468.

[104] Primack, R. B. (1993): Essentials of conservation biology. - Sinauer Associates, Sunderland.

[105] Primack, R. B. (2004): A primer of conservation biology. 3rd edition. - Sinauer Associates, Sunderland.

[106] Puryear, S., Bruers, S., Erdős, L. (2017): On a failed defense of factory farming. - Journal of Agricultural and Environmental Ethics 30: 311-323

[107] Rachels, J. (1990): Created from animals: The moral implications of Darwinism. Oxford University Press, Oxford.

[108] Regan, T. (1983): The case for animal rights. - University of California Press, Berkeley.

[109] Reyers, B., Roux, D. J., O'Farrell, P. J. (2010): Can ecosystem services lead ecology on a transdisciplinary pathway? - Environmental Conservation 37: 501-511.

[110] Ridder, B. (2008): Questioning the ecosystem services argument for biodiversity conservation. - Biodiversity and Conservation 17: 781-790.

[111] Rossi, J., Garner, S. A. (2014): Industrial farm animal production: a comprehensive moral critique. - Journal of Agricultural and Environmental Ethics 27: 479-522.

[112] Rösch, C. (2002): Trends in der Ernährung - eine nachhaltige Entwicklung? - GAIA 11: 119-123.

[113] Rushforth, R., Moreau, M. (2013): Finding your dog's ecological 'pawprint': a hybrid EIO-LCA of dog food manufacturing. Project report. - SSEBE-CESEM, Tempe.

[114] Ryder, R. D. (1975): Victims of science: The use of animals in research. - Davis-Poynter Ltd., London.

[115] Sagoff, M. (1984): Animal liberation and environmental ethics: bad marriage, quick divorce. - Osgoode Hall Law Journal 22: 297-307.

[116] Saláta, D., Falusi, E., Wichmann, B., Házi, J., Penksza, K. (2012): Faj- és vegetációösszetétel elemzése eltérő legeltetési terhelés alatt a cserépfalui és az erdőbényei fáslegelők különböző növényzeti típusaiban. - Botanikai Közlemények 99: 143-159.

[117] Salles, J. M. (2011): Valuing biodiversity and ecosystem services: why put economic values on nature? Salles JM (2011) Valuing biodiversity and ecosystem services: Why put economic values on nature? - Comptes Rendus Biologies 334: 469-482.

[118] Schumacher, E. F. (1973): Small is beautiful: Economics as if people mattered. - Harper and Row, New York.

[119] Schweitzer, A. (1923): Kulturphilosophie: Kultur und Ethik. - C.H. Beck, München.

[120] Singer, P. (1975): Animal liberation. - Random House, New York.

[121] Soulé, M. E. (1985): What is conservation biology? - Bioscience 35: 727-734.

[122] Soulé, M. E. (1986): Conservation biology and the "real world". - In: Soulé, M. E. (ed.) Conservation biology: the science of scarcity and diversity. Sinauer Associates, Sunderland, pp. 1-12. 
[123] Soulé, M. E., Wilcox, B. A. (1980): Conservation biology: Its scope and its challenge. In: Soulé, M. E., Wilcox, B. A. (eds.) Conservation biology: An evolutionary-ecological perspective. Sinauer Associates, Sunderland, pp. 1-8.

[124] Steinfeld, H., Gerber, P., Wasenaar, T., Castel, V., Rosales, M., de Haan, C. (2006): Livestock's long shadow. Environmental issues and options. - UN FAO, Rome.

[125] Stewart, G.B., Pullin, A. S., Coles, C. F. (2007): Poor evidence-base for assessment of windfarm impacts on birds. - Environmental Conservation 34: 1-11.

[126] Stoll-Kleemann, S. (2014): Fleischkonsum im 21. Jahrhundert: ein Thema für die humanökologische Forschung. - GAIA 23: 366-368.

[127] Strong, D. H. (1988): Dreamers and defenders: American conservationists. - University of Nebraska Press, Lincoln.

[128] Switzer, J. V. (2003): Environmental activism: A reference handbook. - ABC-CLIO, Santa Barbara.

[129] Taylor, P. (1981): The ethics of respect for nature. - Environmental Ethics 3: 197-218.

[130] Thompson, T. R., Lapointe, G. D. (1995): Learning from animal activists: A workshop approach. - Wildlife Society Bulletin 23: 588-593.

[131] Thoreau, H. D. (1854): Walden, or life in the woods. - Ticknor and Fields, Boston.

[132] van Dooren, T. (2011): Invasive species in penguin worlds: an ethical taxonomy of killing for conservation. - Conservation and Society 9: 286-298.

[133] Ventura, B. A., von Keyserlingk, M. A. G., Weary, D. M. (2015): Animal welfare concerns and values of stakeholders within the dairy industry. - Journal of Agricultural and Environmental Ethics 28: 109-126.

[134] Vitousek, P. M., Mooney, H. A., Lubchenco, J., Melillo, J. M. (1997): Human domination of earth's ecosystems. - Science 277: 494-499.

[135] Waldau, P. (2011): Animal rights: What everyone needs to know. - Oxford University Press, Oxford,

[136] Wellock, T. R. (2007): Preserving the nation: The conservation and environmental movements 1870-2000. - Harlan Davidson, Wheeling.

[137] Wenz, P. S. (1993): Minimal, moderate, and extreme moral pluralism. - Environmental Ethics 15: 61-74.

[138] Western, D. (1989): Population, resources, and environment in the twenty-first century. In: Western, D., Pearl, M. C. (eds.) Conservation for the twenty-first century. Oxford University Press, Oxford, pp. 11-25.

[139] Westhoek, H., Lesschen, J. P., Rood, T., Wagner, S., De Marco, A., Murphy-Bokern, D., Leip A., van Grinsven, H., Sutton, M. A., Oenema, O. (2014): Food choices, health and environment: effects of cutting Europe's meat and dairy intake. - Global Environmental Change 26: 196-205.

[140] Wichmann, B., Szentes, Sz., Házi, J., Sutyinszki, Zs., S. Falusi, E., Besnyői, V., Penksza, V., Fehér, Zs., Nagy, A., L. Szabó, Zs., Kiss, T., Penksza, K. (2013): Magyar szürke szarvasmarhával végzett legeltetés hatása a vegetáció fajösszetételére Balaton-felvidéki mintaterületeken. - Gyepgazdálkodási Közlemények 2013: 73-79.

[141] Wildes, F. T. (1995): Recent themes in conservation philosophy and policy in the United States. - Environmental Conservation 22: 143-150.

[142] Williams, J., Crutzen, P. J. (2013): Perspectives on our planet in the Anthropocene. Environmental Chemistry 10: 269-280.

[143] Wolf, J. C. (1996): Animal welfare policy between democracy and lobbyism. - ALTEX Alternativen zu Tierexperimenten 13: 111-117.

[144] Zahn, A., Juen, A., Traugott, M., Lang, A. (2007): Low density cattle grazing enhances arthropod diversity of abandoned wetland. - Applied Ecology and Environmental Research 5: 73-86. 